\title{
德川時代人口に關する新資料
}

\author{
須田昭義
}

德川時代人口に關しては關山直太郎氏著「近世日本人口の研究」(昭和 23 年)によつて呚 えられるとてろが多かつた。頃日泎に入れた「三暇謾錄」と題する寫本（天保年間筆寫のも のと思われる）に、前揭本に載せられていない享保 6 丑年の國別人口その他があるので書留 めておをたい。

周知の如く享保 6 年は德川時代最初の全國人口を集計した年であつて、その總人口は寬政 年間太田南畧が編した「竹橋餘筆別集 8 」によつて $26,065,422$ 人であつ壳てとが知られて いる。その國別人口は知られていなかつたが、本珰「國中人數石高之事!の項に天保 5 午年 の人口及び石高とともに併記してあり、始めて當侍の國別人口が知らる」に至つたので㐫 る。その數㳉次通りである。

\begin{tabular}{|c|c|c|c|c|c|c|}
\hline 城 & 564,994 人 & 信 & 693,947 & 備 & 前 & 338,523 \\
\hline 大 & 413,331 & 上 & 569,550 & 備 & 中 & 333,731 \\
\hline 內 & 243,820 & 下 & 560,020 & 備 & 後 & 321,008 \\
\hline 泉 & 218,405 & 陸 & $1,962,839$ & 安 & 藝 & 361,431 \\
\hline 津 & 809,242 & 蝦荑松前 & 15,615 & 周 & 防 & 262,927 \\
\hline 賀 & 95,978 & 出 & 877,650 & 長 & 門 & 212,124 \\
\hline 勢 & 543,737 & 若 & 86,598 & 紀 & 伊 & 519,022 \\
\hline 摩 & 31,856 & 越 & 367,652 & 淡 & 路 & 105,226 \\
\hline 張 & 554,561 & 加 & 206,933 & 阳 & 波 & 342,386 \\
\hline 河 & 416,204 & 能 & 152,113 & 讃 & 峧 & 334,153 \\
\hline 江 & 342,663 & 越 & 314,158 & 伊 & 䂈 & 504,045 \\
\hline 河 & 245,834 & 越 & 932,461 & \pm & 佐 & 351,547 \\
\hline 豆 & 96,650 & 佐 & 95,748 & 筑 & 前 & 302,160 \\
\hline 斐 & 291,168 & 丹 & 284,893 & 筑 & 後 & 266,426 \\
\hline 模 & 312,638 & 丹 & 125,276 & 显 & 前 & 248,187 \\
\hline 藏 & $1,903,316$ & 但 & 149,732 & 豐 & 後 & 524,394 \\
\hline 房 & 115,579 & 因 & 122,030 & 肥 & 前 & 609,926 \\
\hline 總 & 407,553 & 伯 & 132,981 & 肥 & 後 & 614,007 \\
\hline 總 & 542,661 & 出 & 222,330 & 日 & 向 & 211,614 \\
\hline 陸 & 712,387 & 石 & 207,965 & 大 & 隅 & 112,616 \\
\hline 江 & 602,367 & 䧔 & 18,133 & 薩 & 摩 & 149,039 \\
\hline 濃 & 545,919 & 播 & 633,725 & 壹 & 岐 & 19,993 \\
\hline 驒 & 67,032 & 美 & 194,226 & 對 & 馬 & 16,467 \\
\hline
\end{tabular}

男女別人數、全國總人數は記されていない。國每つを合計すると $26,065,422$ 人となり竹 橋餘筆別集所載の數值に合致する。然してれらの數檤注最初の不慣交調查である上沉、「人 數之儀去年分成共、當年分成共、委〈相知方候人數高認め可被差活候。左候は心゙们之年之人 
數高に候との儀、可被書載候云队」と指令され、從つて嚴密にいえば享保 6 年の人口でない ととが明らかであつて、その信賴性が疑われる點が多い。

假にての國別人吕に基礎をおいて，「日本民族」（日本人類學會編、昭和 27 年刊）中の 「我國人口密度の變遷と文化中心地帶の移動」に載せたと同じ方法で 1 平方粁について人口 密度を算出すると、全國平均では享保 6 年 $(1721)$ は 90 、文化元年 $(1804)$ は 89 となり、兩 者間に差はないものと認められる。然し地方的にはかなり違いのみられるものがある。

\begin{tabular}{|c|c|c|c|c|c|c|c|c|c|}
\hline & & 享保 6 年 & 文化元年 & 差 & & & 享保 6 年 & 文化元年 & 差 \\
\hline 下 & 野 & 87 人 & 63 人 & -24 人 & 尾 & 張 & 343人 & 376人 & +33 人 \\
\hline 常 & 陸 & 133 & 91 & -42 & 志 & 摩 & 115 & 137 & +22 \\
\hline 武 & 藏 & 317 & 277 & -40 & 出 & 雲 & 83 & 104 & +21 \\
\hline 伊 & 賀 & 163 & 136 & -27 & 安 & 藝 & 79 & 109 & +30 \\
\hline 山 & 城 & 499 & 415 & -84 & 周 & 防 & 86 & 117 & +31 \\
\hline 大 & 和 & 112 & 92 & -20 & 淡 & 路 & 178 & 207 & +29 \\
\hline 和 & 泉 & 428 & 396 & -32 & 阿 & 波 & 83 & 103 & +20 \\
\hline 河 & 內 & 376 & 332 & -44 & 讃 & 岐 & 180 & 213 & +33 \\
\hline 伊 & 豆 & 68 & 88 & +20 & 薩 & 摩 & 40 & 64 & +24 \\
\hline 安 & 房 & 202 & 235 & +33 & 壹 & 岐 & 144 & 184 & +40 \\
\hline
\end{tabular}

これを通覽すると關東一帶、戗內一乖の減少が激しく、尾張、山陰、安藝一周防、四國東 部並びに所火の牛島及び島嶼の密度が奮加しているように見受けられる。

以上「三睱謾錄」には享保 6 年と天保 5 年の國別人口老列舉した後に、武藏國のみについ て享保 6 年から天保 5 年までの 6 年每て調查された人口を列記している。

\begin{tabular}{|c|c|c|c|c|c|c|}
\hline 享保 & 6 丑年 & 人數 & $1,903,316$ 人 & 天明 6 午年 & 人數 & $1,626,968$ 人 \\
\hline 同 & 12 午 年D & 人數 & $1,800,783$ 人 & 寬政 4 子年 & 人數 & $1,634,048$ 人 \\
\hline 同 & 17 子年 & 人數 & $1,850,599$ 人 & 10 午年 & 人数 & $1,666,131$ 人 \\
\hline 元 交 & 3 午年 & 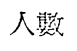 & $1,737,205$ 人 & 炎化元子年 & 人數 & $1,654,368$ 人 \\
\hline 延享 & 元子 年 & 人數 & $1,787,021$ 人 & 7 午年 & 人數 & $1,674,669$ 人 \\
\hline 寬·㢟 & 3 午年 & 人数 & 1,771,214人 & 同 13 子年 & 人數 & $1,675,300$ 人 \\
\hline 瓔 曆 & 6 子年 & 人數 & $1,774, \mathrm{C} 64$ 人 & 文政 5 午年 & 人數 & $1,694,255$ 人 \\
\hline 同 & 12 午年 & 人數 & $1,737,158$ 人 & 同 11 子年 & 人㛝 & $1,717,455$ 人 \\
\hline 明 和 & 5 子年 & 人數 & $1,753,994$ 人 & 天保 5 午年 & 人數 & $1,714,054$ 人 \\
\hline 安永 & 3 午年 & 人數. & $1,707,719$ 人 & 同 11 子年 & 人蘩 & \\
\hline 同 & 9 子年 & 人數 & $1,702,7,84$ 人 & 弘化 3 午年? & 人數. & \\
\hline
\end{tabular}

前揭關山氏の著書によると元文 3 年、文化 7 年、同 13 年、天保 11 年贡び弘化 4 年以後

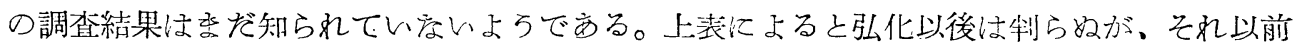
には少なくとも武藏國汇關して活、正確に 6 年每て人口調查がなされ省てとは確かであり、

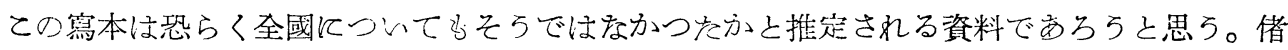
上揭の數值をみると、享保 6 年と同 11 年の 5 年間に 10 莴人、享保 17 年と元文 3 年の 6 年

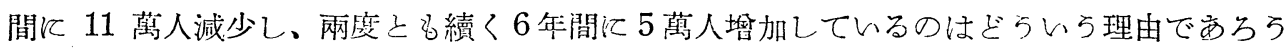
か。享保 6 年のが過大に、元文つが過少に算定されをとすれば、減少の傎向が比較的滑らか 


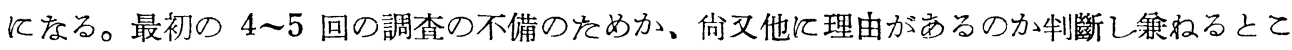
ろである。然し大體の傾向は初め人口の減少をみ、天明 6 年 (1786) を最低沉して、以後は 篔加を續け、吹栕錄によると弘化 3 年 (1846) には $1,777,371$ 人に達している。

佮乙の寫本には最初に「國中人別御改之事」「先年來人數增減之分前後之帳面突合之事」 「國中人數石高之事」郎ち寬延 3 年の人口調查結果が記され、最後には「諸大名人數石高之 事」「大名悉御家來に成る事」「諸大名參勤之節從者御定之事」「諸大名諸士江被仰渡御儉 約之事」「江城御造營之事」というのがついている。

(東京大學理學部人嗩學教室)

\section{New Data on the Population in the Tokugawa Period} AKIYOSHI SUDA

I bought a manuscript some days ago and found in it some descriptions on the population of each Province (Kuni) of Japan in the year 1721, the first census in the Tokugawa Period, which has not been known, hetherto, to the present time scholars. The numerals will be seen in the Japanese text. 